\title{
Trichomycterus uisae: a new species of hypogean catfish (Siluriformes: Trichomycteridae) from the northeastern Andean Cordillera of Colombia
}

\author{
Cesar A. Castellanos-Morales
}

Trichomycterus uisae, a new species of hypogean catfish, is described from Cueva El Misterio located in the upper Sogamoso river basin of the Departamento de Santander in the northeastern portion of the Andean range of Colombia. The new species has a characteristic dark bluish-gray band from the head to the origin of the dorsal fin, five to nine opercular odontodes, and the anterior and posterior fontanels separated but connected by a narrow channel. A comparative analysis with epigean species from Colombia and troglobitic Trichomycterus from South America is presented.

Trichomycterus uisae, uma nova espécie de bagre hipógeo, é descrita da Caverna El Misterio, localizada na parte alta da bacia do rio Sogamoso, no Departamento de Santander na parte nordeste dos Andes da Colômbia. A nova espécie tem uma banda cinza-azulada caraterística que vai desde a cabeça até a origem da nadadeira dorsal; cinco a nove odontódeos operculares; e fontanelas anterior e posterior separadas, mas conectadas por um canal estreito. Uma análise comparativa com espécies epígeas da Colômbia e Trichomycterus troglóbios da América do Sul é apresentada.

Key words: Taxonomy, Troglomorphic, Cave, Sogamoso river basin.

\section{Introduction}

The catfish family Trichomycteridae comprises small to medium-sized freshwater catfishes that are widely distributed in Central and South America, on both sides of the Andes, from sea level to $4500 \mathrm{~m}$ (de Pinna \& Wosiacki, 2003; Nelson, 2006). The Trichomycteridae is the third largest family of Neotropical catfishes with more than 207 species and 41 valid genera described (Ferraris, 2007). It is also one of the most successful groups occupying cave habitats in South America. With about 100 nominal species (de Pinna, 1992), Trichomycterus is the most diverse genus in the family, but its monophyletic status has been questioned by several authors (Baskin, 1973; de Pinna, 1989; Costa \& Bockmann, 1993; Wosiacki, 2002).

The Trichomycteridae has 12 species described from hypogean environments (Ardila-R., 2006; CastellanosMorales, 2007; Bichuette \& Trajano, 2008; Bichuette et al., 2008), of which five correspond to the genus Trichomycterus, inhabiting caves of Bolivia (Trichomycterus chaberti Durand,
Umayalanta cave), Brazil (T. itacarambiensis Trajano \& de Pinna, Olhos d'Água cave), Venezuela (T. spelaeus DoNascimiento, Villarreal \& Provenzano, Punto Fijo cave), and Colombia (T. sandovali Ardila-R., Don Juan cave); and T. santanderensis Castellanos-Morales, El Puente cave). There are reports of four additional subterranean populations of Trichomycterus in South America, one from the Colombian Andes (Sket, 1988), one from Guacharo cave in Venezuela, previously considered to be a hypogean population of $T$. conradi (DoNascimiento \& Villarreal, 2005), and two from Brazil (Bichuette \& Trajano, 2008).

A total of 24 species of Trichomycterus have been reported for Colombia (Eigenmann, 1918; Dahl, 1971; Fernandez \& Schaefer, 2005; Maldonado-O. et al., 2005; Ardila-R., 2006; Castellanos-Morales, 2007), of which 22 occur in epigean environments. This paper describes a new species of hypogean troglomorphic Trichomycterus from Cueva El Misterio, in the upper Sogamoso River basin, Departamento de Santander, Colombia (Fig. 1).

Department of Biology, University of Puerto Rico, Mayagüez, Puerto Rico 00680. cesarcas1a@gmail.com 


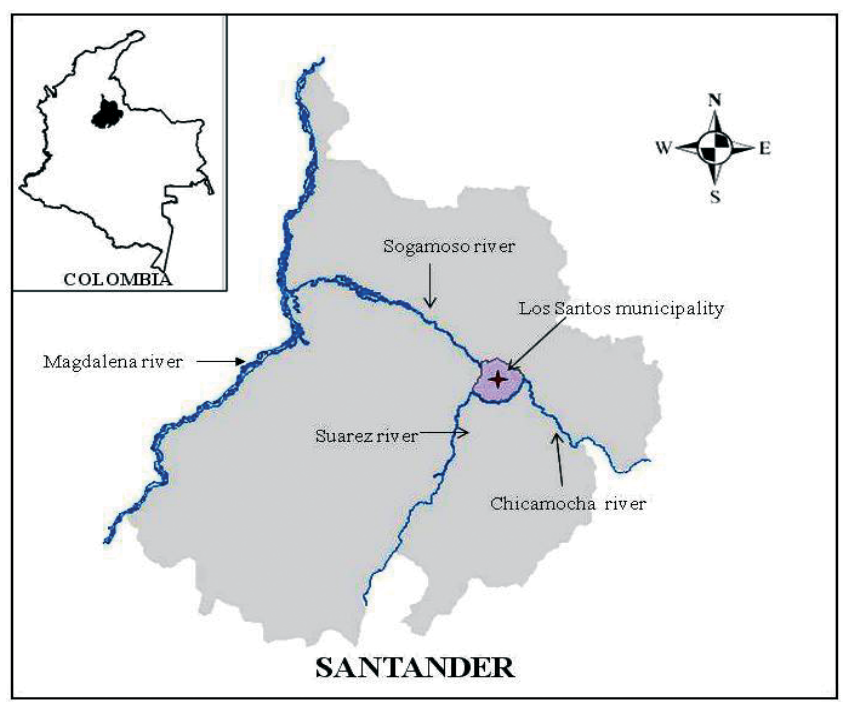

Fig. 1. Map of Santander Departament in northeastern Colombia with the approximate location of the collecting site of Trichomycterus uisae, in Cueva El Misterio, upper Sogamoso River basin.

\section{Materials and Methods}

Measurements were taken point-to-point with dial calipers on the left side of each specimen with the aid of a stereomicroscope. Methodology and terminology for measurements and counts follow de Pinna (1992). Osteological data were obtained from two non-type specimens prepared following the procedure of Taylor \& Van Dyke (1985). Osteological nomenclature follows de Pinna (1989) and for the cephalic laterosensory system, Arratia \& Huaquin (1995). Color was determined according to the Munsell soil color chart (1994). Morphological data for troglomorphic species other than Trichomycterus santanderensis CastellanosMorales (2007) were based on information from the literature.

Acronyms and abbreviations used are, C\&S: cleared and stained; HL: head length; M: Munsell soil color chart; SL: standard length; ANSP: Academy of Natural Sciences, Philadelphia; CAC-CDMB: Corporación Autónoma para la Defensa de la Meseta de Bucaramanga; IAvH-P: Instituto Alexander von Humboldt; UIS-T: Universidad Industrial de Santander.

\section{Results}

\section{Trichomycterus uisae, new species}

Figs. 2 - 3

Holotype. CAC-CDMB 72.5 mm SL, Colombia, Departamento de Santander, Municipio de Los Santos, Vereda Mesa de Los Santos, Acuarela road $3.5 \mathrm{~km}$, Cueva El Misterio (06 50 '21'N, 7305' $18^{\circ}$ 'W, elevation $1600 \mathrm{~m}$ ), upper Sogamoso River basin; C. Castellanos-M, L. L. Marino-Zamudio \& M. Pardo-Peñaloza, 1 Nov 2006.

Paratypes. All collected at holotype locality. ANSP 187498, 45.5 mm SL, C. Castellanos-M \& L. L. Marino-Zamudio, 28 Feb 2007. CAC-CDMB 88, 55.9 mm SL, C. Castellanos-M \& L. L. MarinoZamudio, 28 Feb 2007. IAvH-P 10806, 2, 52.2-57.0 mm SL, C. Castellanos-M, L. L. Marino-Zamudio \& M. Pardo-Peñaloza, 1 Mar 2007. UIS-T 1698, 49 mm SL, C. Castellanos-M, L. L. MarinoZamudio \& M. Pardo-Peñaloza, 1 Mar 2007. UIS-T 1699, 43.5 mm SL, C. Castellanos-M, L. L. Marino-Zamudio \& M. PardoPeñaloza, 2 Mar 2007.

Non-type material. All collected at holotype locality. CAC-CDMB 90, 2 C\&S, 32.1-41.1 mm SL, 1 Mar 2007. CAC-CDMB 91, 45.5 mm SL, 2 Mar 2007. CAC-CDMB 92, C\&S, 28.3 mm SL, 2 Mar 2007. UIS-T 1700, 39.8 mm SL, C. Castellanos-M. \& L. L. MarinoZamudio, 2 Mar 2007.

Diagnosis. Trichomycterus uisae (Figs. 2-3) is distinguished from both epigean and troglomorphic species of the genus by the following combination of characters: anterior and posterior fontanels separated but connected by a narrow channel ( $v s$. fontanels separated by epiphyseal bar); five to nine opercular odontodes (vs. 8 to 16); reduced mouth width (32.6$41.2 \%$ of HL); relatively deep head (48.6-66.3\% of HL); reduced pigmentation (except for epigean T. gorgona and caverestricted congeners $T$. chaberti, T. itacarambiensis, $T$. sandovali, T. santanderensis and T. spelaeus) consisting of a narrow predorsal dark bluish-gray stripe from nape to origin of dorsal fin and ground coloration light-brown without spots ( $v s$. pigmented body with dark spots); variable reduction of eyes from 7.4 to $11.1 \%$ of HL (except for epigean $T$. gorgona and hypogean $T$. chaberti, T. itacarambensis and $T$. santanderensis); extended nasal, maxillary and rictal barbels (85.2-108\%, 93.6-111.8\% and 55.1-70.2\% of HL, respectively); caudal fin with slightly convex margin, dorsal lobe of caudalfin longer than ventral lobe. Other characters shared with

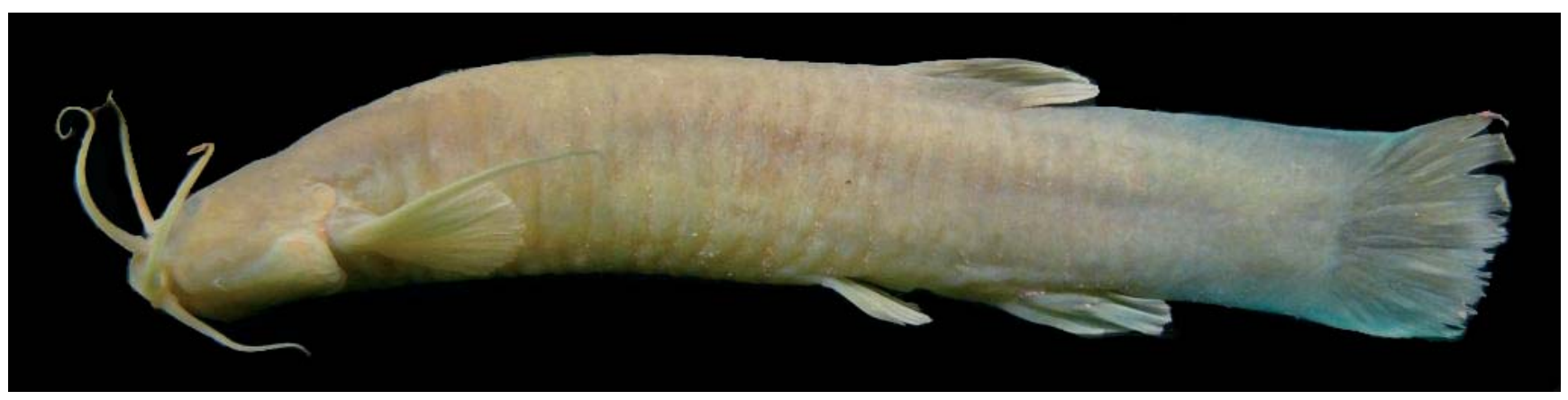

Fig. 2. Trichomycterus uisae, holotype, CAC-CDMB $72.5 \mathrm{~mm}$ SL. Cueva El Misterio, upper Sogamoso River basin, Santander, Colombia. Lateral view of the left side. 


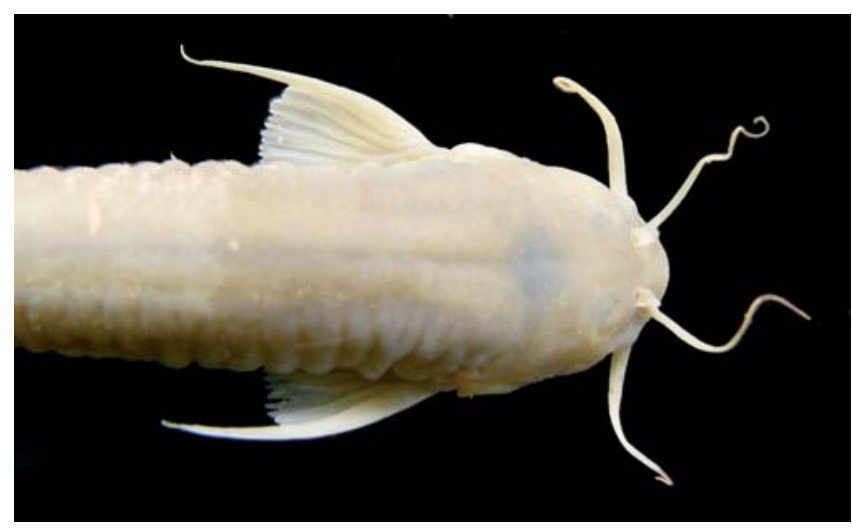

Fig. 3. Trichomycterus uisae, holotype, CAC-CDMB 72, 54 mm SL. Cueva El Misterio, upper Sogamoso River basin, Santander, Colombia. Dorsal view of head.

various other species of Trichomycterus yet useful for identification include origin of pelvic fin anterior to vertical through dorsal-fin origin; short caudal peduncle (19-21.9\% of SL); tip of first pectoral-fin ray prolonged as a long filament (52.1$89 \%$ of pectoral-fin length) and pelvic fins not widely separated.

Description. Morphometric data presented in Table 1. Body elongated, deeper than wide, gradually deeper from trunk toward caudal peduncle; dorsal profile of trunk convex. Ventral profile of trunk straight. Dorsal and ventral profiles of caudal peduncle slightly convex. Integument thick with lateral cutaneous folds forming vertical rings between pectoral and anal fins in specimens preserved in alcohol. Anal and urogenital openings closer to pelvic-fin base than to anal-fin origin, totally covered when pelvic fin extended. Free vertebrae 35. Pleural ribs 11-12.

Head wide, trapezoidal, depressed in dorsal view. Dorsal profile of head straight, ventral and lateral profiles convex. Eye small, black, rounded, well defined, with variable diameter, positioned dorsally on anterior half of head. Mouth subterminal, with corners oriented backwards. Lower lip with conspicuously fleshy lateral lobes. Teeth conical, curved, arranged in 3-4 irregular rows on upper jaw and three rows on lower jaw. Jaw muscles not particularly developed and not bulging from surface of head. Neurocranium with elongate mesethmoid T-shape. Anterior fontanel small, oval in shape, located between frontals at level of infraorbital laterosensory canal exit 10-11. Posterior fontanel long and broad. Anterior one-third of posterior fontanel situated between frontal bones, with remainder in anterior portion of supraoccipital bone (Fig. 4). Both fontanels connected by a narrow channel. Branchial membranes thick, united to isthmus anteromedially and forming free fold across isthmus. Gill opening wide. Seven branchiostegal rays (Fig. 5a), six externally visible from below. Nasal and maxillary barbels surpassing base of pectoral fin. Maxillary barbel longer than nasal barbel. Anterior nostril

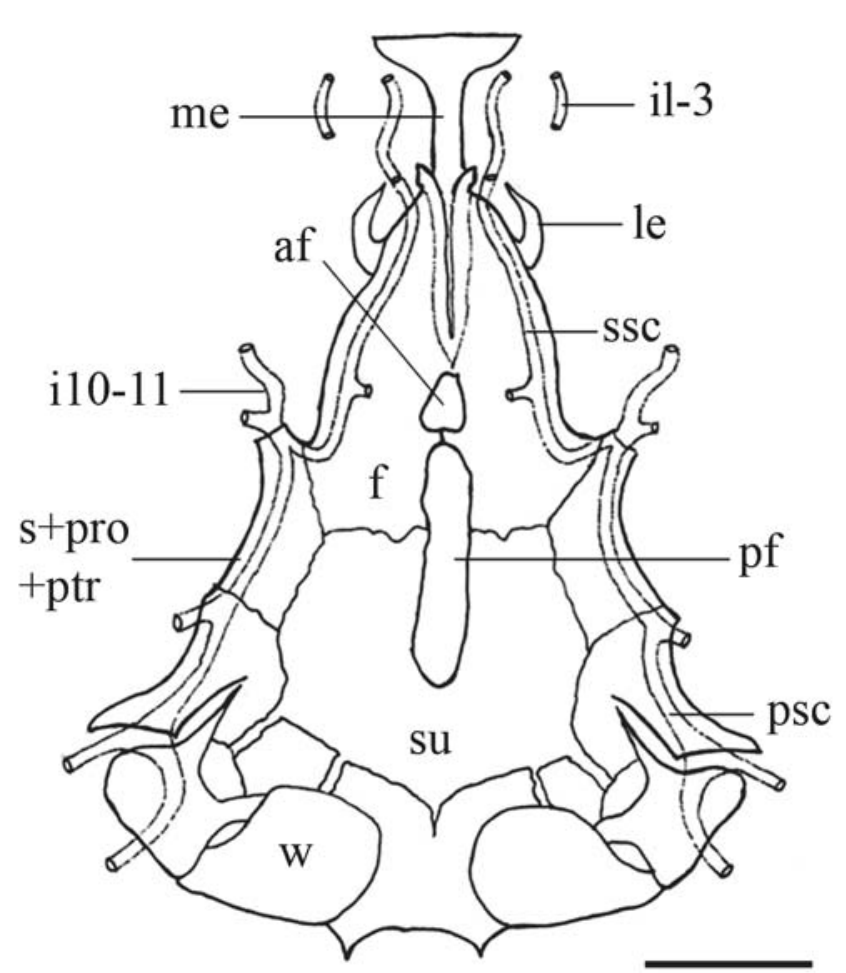

Fig. 4. Dorsal view of the neurocranium of Trichomycterus uisae. CAC-CDMB 90, $32.1 \mathrm{~mm} \mathrm{SL}$. af: anterior fontanel; f: frontal; i1-3: infraorbital sensory pores 1-3; i10-11: infraorbital sensory pores 10-11; le: lateral ethmoid; me: mesethmoid; pf: posterior fontanel; psc: postotic sensory canal; $\mathrm{s}+$ pro+ptr: sphenotic + prootic+pterosphenoid; su: supraoccipital; ssc: supraorbital sensory canal; w: Weberian capsule. Scale bar $=1 \mathrm{~mm}$.

surrounded by slightly raised thick integument, continuous with nasal barbel, both forming a tubular-shaped structure around nostril. Posterior nostril oriented transversally, its anterior edge delimited by thin and long flap of integument. Interopecular patch of odontodes well developed, with 27-32 conical and elongated odontodes arranged in four irregular rows, with interopercular odontodes on posterior edge larger. Opercular patch of odontodes small, with 5-9 conical odontodes arranged in three irregular rows (Fig. 5b).

Pectoral fin rounded with i,8 rays. First ray thin and fragile, prolonged as a long filament. Scapulocoracoid with long anteriorly directed process, located close to first pectoral-fin ray base (Fig. 6). Dorsal-fin rounded, located posterior to vertical through midbody, with iv, 7 rays (only two unbranched rays externally visible). First pterygiophore inserted between neural spines of $15-16^{\text {th }}$ free vertebra. Pelvic-fin rays i,4, with a lateral splint. Pelvic-fin origin anterior to vertical through dorsal-fin origin and its posterior edge slightly surpasses urogenital opening. Pelvic-fin bases not widely separated. Basipterygium with two long anterior processes narrowing 

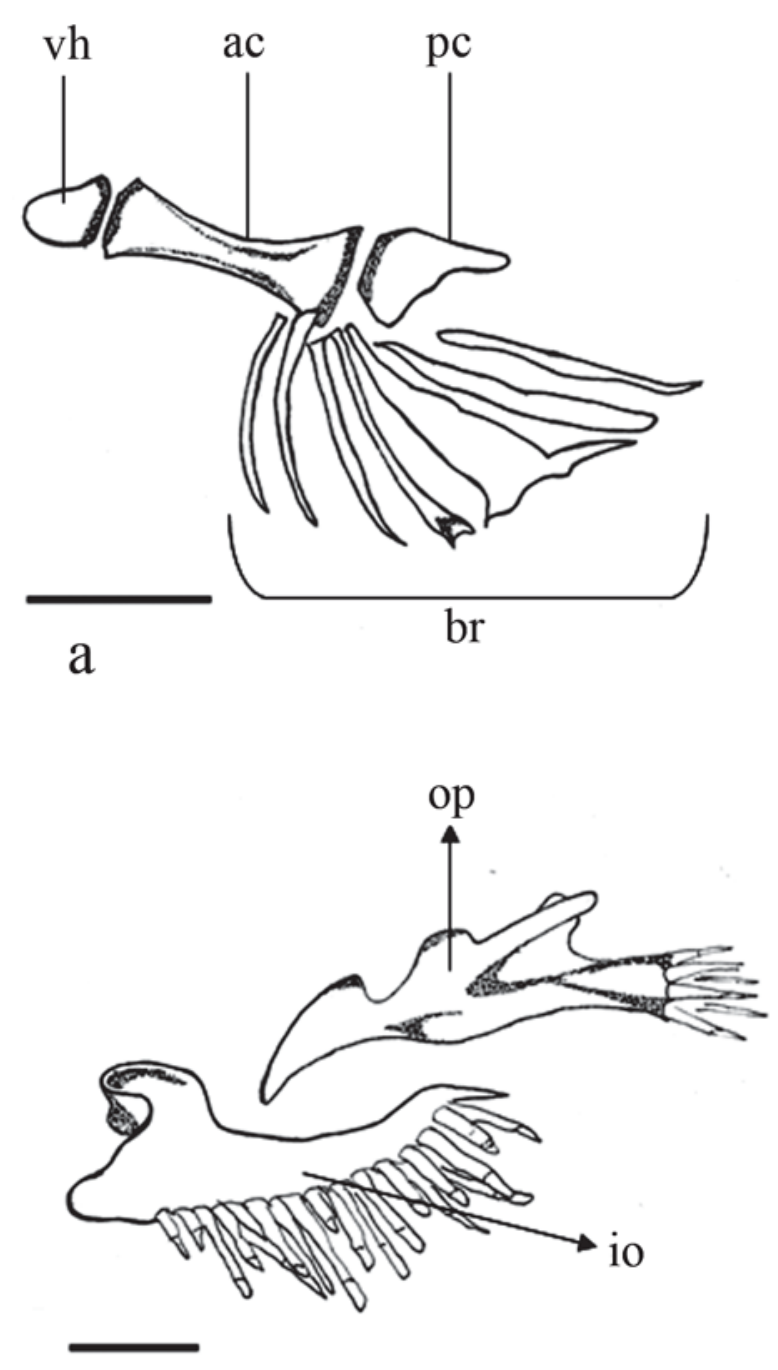

b

Fig. 5. a. Left hyoid arch of Trichomycterus uisae in ventral view. CAC-CDMB 90, $32.1 \mathrm{~mm} \mathrm{SL}$. ac: anterior ceratohyal; br: branchiostegal rays; pc: posterior ceratohyal; vh: hypohyal. b. Opercular series of Trichomycterus uisae. op: opercle; io: interopercle. Scale bar $=1 \mathrm{~mm}$.

from base to distal tip, one or two medial processes and one short posterior process (Fig. 7). Anal-fin similar to dorsal fin, but smaller, with ii, 5 rays, its origin at level of last dorsal-fin ray. First pterygiophore inserted between hemal spines of free vertebrae 20-21. Caudal-fin rays i, 5+6, i. Parhypural and hypurals $1+2$ associated with eight rays, hypural 3 with 3 rays , and hypurals $4+5$ with 3 rays. 17-18 dorsal and 12 ventral procurrent rays. Caudal-fin edge slightly convex, uppermost rays larger. Caudal skeleton with neural spine of preural centrum 2 well developed. Hypurals 1 and 2 fused to parhypural; hypural 3 partially fused to hypurals $4+5$ in young specimens (Fig. 8a), and separated in adult specimens (Fig. $8 b)$.

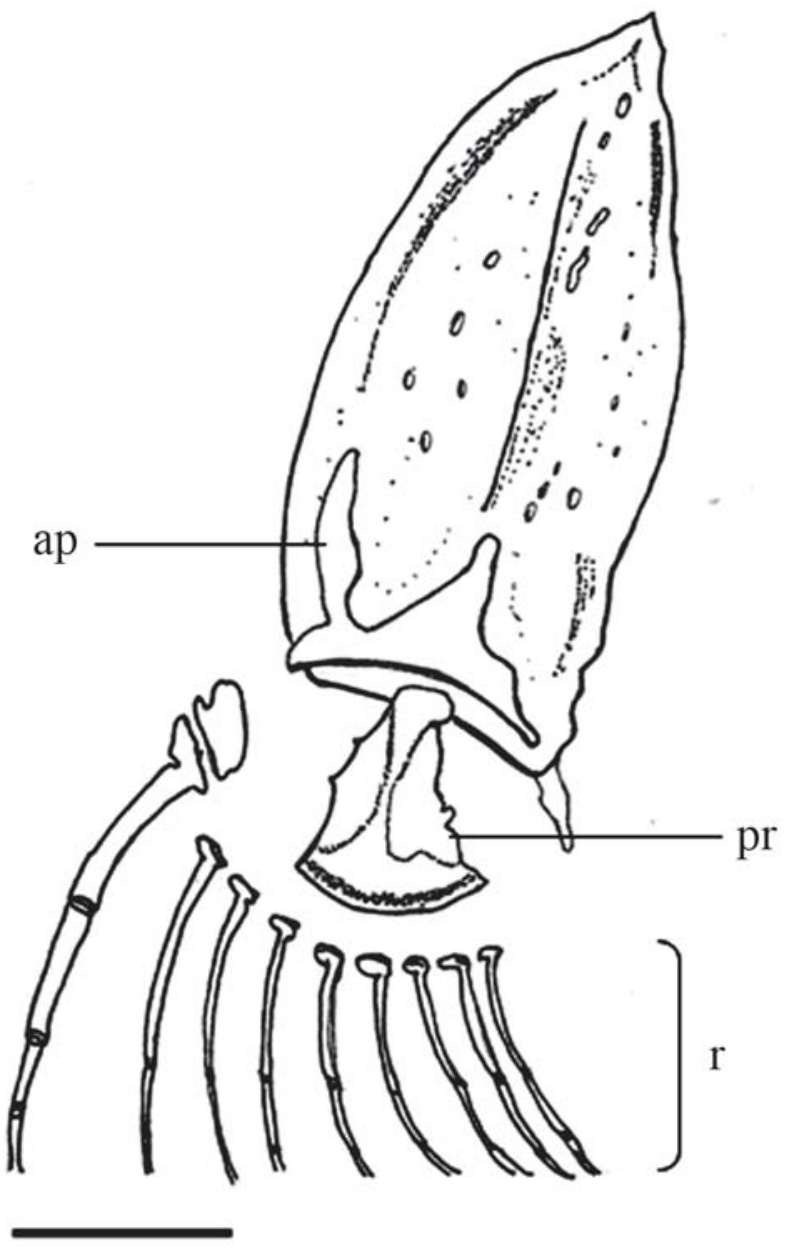

Fig. 6. Ventral view of the right pectoral girdle and fin of Trichomycterus uisae. CAC-CDMB 90, $41.1 \mathrm{~mm} \mathrm{SL}$. ap: anterior process; pr: pectoral radial; r: rays. Scale bar $=1 \mathrm{~mm}$.

Coloration in live specimens. Body color light-brown-(M 10YR $-5 / 6$ ). Base of all fins with yellow tones from base to edge (M $5 \mathrm{YR}-6 / 8$ to $\mathbf{M} 2.5 \mathrm{Y}-7 / 6)$. One predorsal narrow dark bluish gray band (M G-5PB).

Coloration in alcohol. All specimens preserved in alcohol with ground color yellowish (M 10YR - 5/6). Base of all fins with yellow tones (M $2.5 \mathrm{Y}-7 / 6)$, with exception of two nontype specimens with ground color brown-yellowish.

Ecological notes. The Cueva El Misterio is located at the east side of a plateau known as Mesa de los Santos, in the Municipio de los Santos. The plateau has Cretaceous sedimentary rocks and limestones of the Rosablanca Formation (Williams, 1990); reaches 1800 meters above sea level and is located on the oriental versant of the Chicamocha Canyon, in the Colombian Andes, of Santander Department. The cave, with a total of $110 \mathrm{~m}$ of explored passages, is isolated from the 


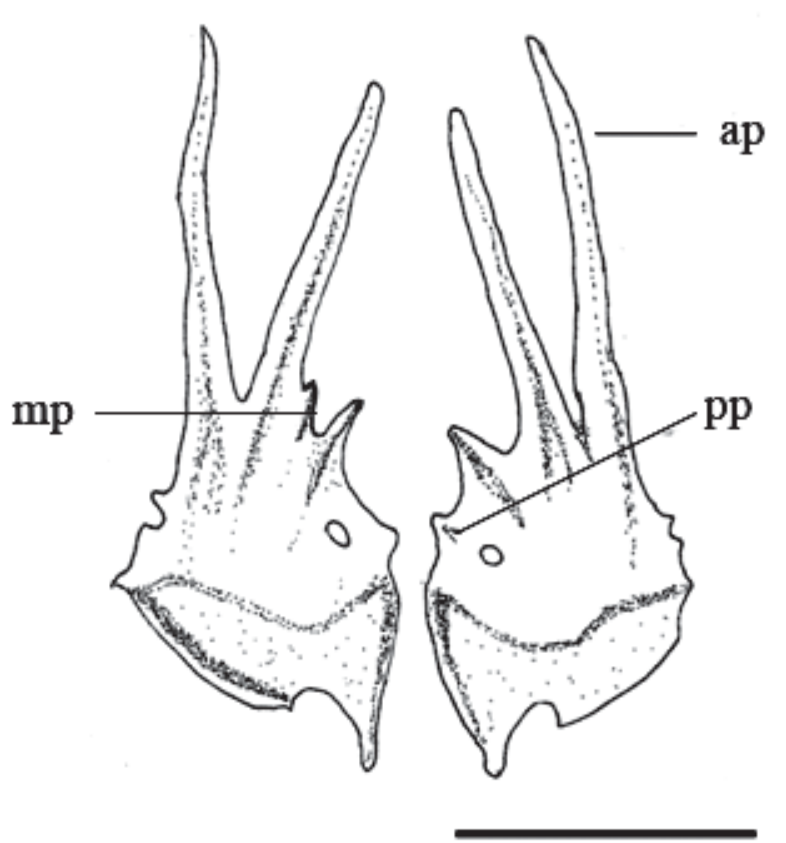

Fig. 7. Ventral view of the basipterygium of Trichomycterus uisae. CAC-CDMB 90, $41.1 \mathrm{~mm}$ SL. ap: anterior process; mp: medial process; pp: posterior process. Scale bar $=1 \mathrm{~mm}$.

epigean stream and is oriented longitudinally with galleries formed by gentle slope tunnels and narrow passageways. The cave has small wells interconnected by reduced descending channels where water infiltration was observed. In dry months, an isolated sump pool was observed at each gallery. The bottom of each well is rocky and contains much sediment composed chiefly of bat excrement. Cydnid bugs (Hemiptera: Heteroptera) were found inside the wells. Diptera, crayfish and bats were observed in the interior of the galleries (Fig. 9). Water temperature, when the holotype was collected, was $20^{\circ} \mathrm{C}$ and cave temperature was $18.5^{\circ} \mathrm{C}$.

Etymology. The specific epithet "uisae" refers to the acronym UIS corresponding to the Universidad Industrial de Santander, in the Departamento de Santander, Colombia. The name is used as a noun in apposition.

Common name. Trepador

\section{Discussion}

According to Trajano (2005), troglomorphic species are restricted to subterranean environments. Characteristics such as some degree of reduction in eye development and pigmentation (Trajano \& de Pinna, 1996; Romero \& Paulson, 2001; Bichuette \& Trajano, 2008) and relatively long barbels (DoNascimiento et al., 2001), are commonly observed in troglomorphic fishes. Trichomycterus uisae exhibits two additional features (well defined lateral cutaneous folds encircling body and dorsal caudal-fin rays longer than ventral
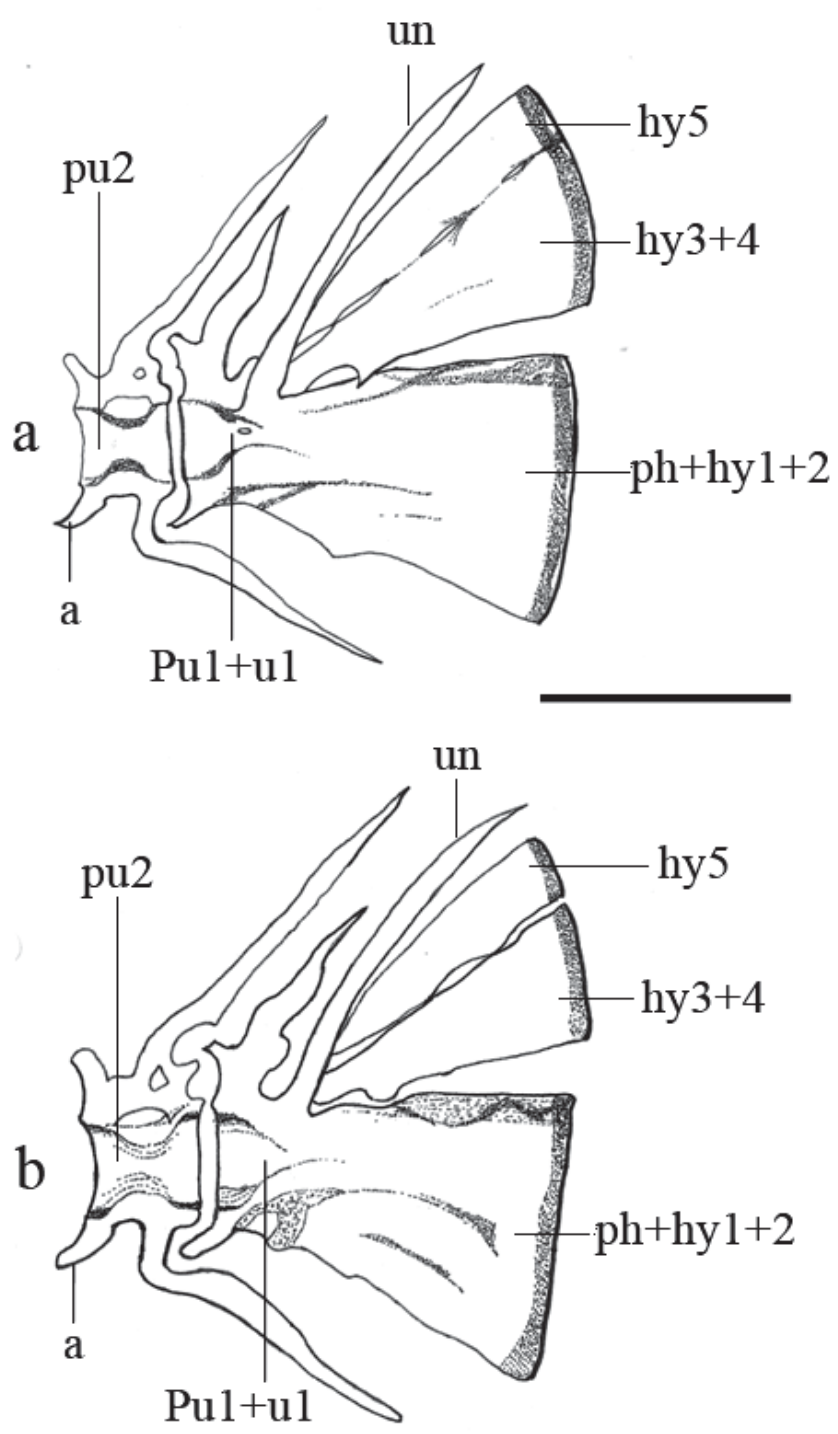

Fig. 8. Caudal skeleton of Trichomycterus uisae. a: CACCDMB 92, $28.3 \mathrm{~mm}$ SL, young specimen. b: CAC-CDMB 90, $41.1 \mathrm{~mm}$ SL, adult specimen. a: apophysis; hy 1-5: hypurals 15; un: uroneural; ph: parhypural; pu1+u1: preural centrum $1+$ ural centrum 1; pu2: preural centrum 2. Scale bar $=1 \mathrm{~mm}$.

rays), that are also present in at least two other hypogean species of the genus: T. santanderensis and T. spealeus. A more comprehensive analysis focusing on the distribution of these conditions in the remaining species of Trichomycterus, both epigean and hypogean, could provide indication as to whether they are related to a hypogean life.

Trichomycterus uisae is a hypogean catfish, that has troglomorphic characters; therefore, a comparison with other troglomorphic species of Trichomycterus was conducted and also with epigean species from the Andean range of Colombia. The results indicate that $T$. uisae is a distinct species (sensu Wheeler \& Platnick, 2000) because it presents a unique combination of characteristics that differentiates it from previously reported epigean and hypogean populations. 


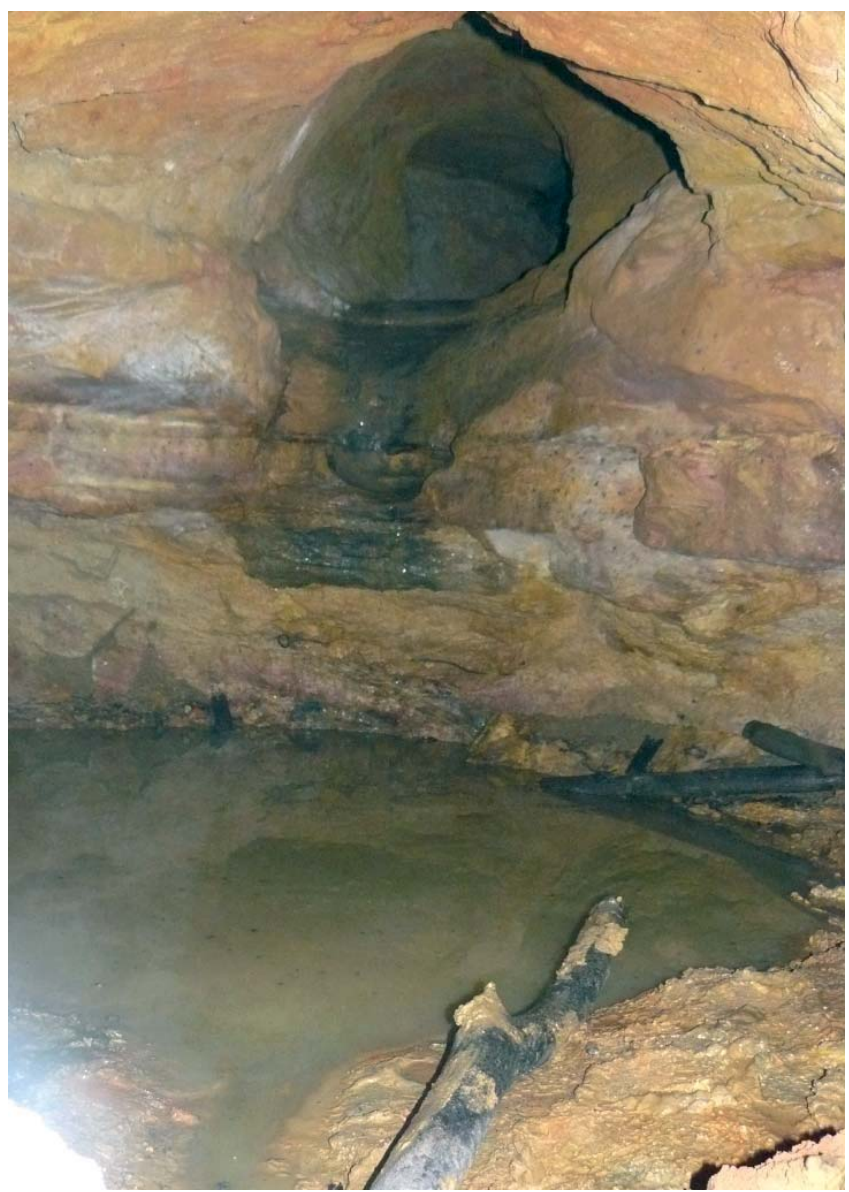

Fig. 9. Inside Cueva El Misterio, upper Sogamoso River basin, Santander, Colombia. Type-locality of Trichomycterus uisae.

There are 22 species of epigean Trichomycterus species reported for Colombia, of which 13 are distributed in the northeastern Andean Cordillera: T. banneaui (Eigenmann, 1912), T. bogotensis (Eigenmann, 1912), T. latidens (Eigenmann, 1918), T. latistriatus (Eigenmann, 1918), T. nigromaculatus Boulenger, 1887, T. retropinnis Regan, 1903, T. romeroi (Fowler, 1941), T. straminius (Eigenmann, 1918), T. stellatus (Eigenmann, 1918), T. striatus (Meek \& Hildebrand, 1913), T. taenia Kner, 1863, T. transandianus (Steindachner, 1915), T. venulosus (Steindachner, 1915).

Trichomycterus uisae is most similar to T. straminius, from which it differs by the position of the dorsal fin, located posterior to the vertical through the pelvic-fin origin ( $v s$. at vertical through the dorsal-fin origin), and by the caudal-fin edge slightly convex ( $v s$. rounded; see Plate 49 in Eigenmann, 1918). Trichomycterus uisae differs from the remaining species by the slightly convex caudal-fin edge with uppermost rays longer ( $v s$. rounded in all species with the exception of $T$. retropinnis, which has a round truncated caudal fin, and $T$. banneaui which has a distinctively emarginated caudal fin; Eigenmann, 1918), and by reduced pigmentation consisting of a narrow predorsal dark bluish- gray stripe and ground coloration light-brown without spots (vs. pigmented body with dark spots).

Trichomycterus uisae is distinguished from epigean species of Trichomycterus distributed throughout northern South America, with exception of Trichomycterus gorgona, by the presence of troglomorphic characters such as: small eyes, reduced pigmentation of head and body, and elongated barbels. It is distinguished from T. gorgona, by its conical teeth ( $v s$. spatulate), pelvic-fin bases not widely separated $(v s$. widely separated) and nine pectoral-fin rays ( $v s$. eight).

From the troglomorphic species of Trichomycterus from South America, Trichomycterus uisae is distinguished from T. sandovali and T. spelaeus by the presence of eyes ( $v s$. absence), the origin of the pelvic fin anterior to the vertical through the dorsal-fin origin ( $v s$. at vertical through the dorsal-fin origin) and fontanels connected by a narrow channel ( $v s$. fontanels separated by epiphyseal bar). Trichomycterus uisae differs from $T$. santanderensis by having the pelvicfin bases not widely separated ( $v s$. widely separated), and the posterior edge of the pelvic fin not reaching the anal-fin origin (vs. pelvic fin reaching anal-fin origin). Trichomycterus uisae is distinguished from $T$. chaberti by the presence of nine pectoral-fins rays ( $v s .10)$ and a long filament on the first pectoral-fin ray ( $v s$. a short filament). Trichomycterus uisae also differs from T. itacarambiensis in body and head pigmentation, consisting of brown-yellowish without spots in the first species ( $v s$. with small, irregular, roundish dark spots in T. itacarambiensis), nine pectoral-fin rays (vs. 6-7) and anal and urogenital openings closer to pelvic-fin base than to anal-fin origin ( $v s$. anal and urogenital openings nearly equidistant from bases of anal and pelvic fins).

The troglomorphic status of Trichomycterus uisae is further supported by the fact that the epigean stream is not

Table 1. Morphometric data of Trichomycterus uisae. Standard length is expressed in millimeters. Measurements 2 to 11 are expressed as percents of standard length, measurements 12 to 19 are expressed as percents of head length.

\begin{tabular}{|c|c|c|c|c|}
\hline & Character & Holotype & $\begin{array}{c}\text { Paratypes } \\
\text { Range }(n=6)\end{array}$ & Mean \\
\hline 1 & Standard length & 54 & $43.5-57.0$ & 53.6 \\
\hline 2 & Total length & 115.8 & $113.1-120.4$ & 116.6 \\
\hline 3 & Body depth & 17.5 & $12.5-19.5$ & 16.2 \\
\hline 4 & Predorsal length & 63.9 & $59.9-65.8$ & 62.2 \\
\hline 5 & Prepelvic length & 56.8 & $53.4-63.5$ & 57.2 \\
\hline 6 & Preanal length & 72.1 & $69.2-73.6$ & 71.4 \\
\hline 7 & Caudal peduncle length & 19.3 & $19-21.9$ & 20.1 \\
\hline 8 & Caudal peduncle depth & 15.7 & $11.5-18.5$ & 14.4 \\
\hline 9 & Dorsal-fin base length & 11 & $10.2-12.4$ & 11.3 \\
\hline 10 & Pelvic-fin base length & 2.8 & $2.4-3.4$ & 2.7 \\
\hline 11 & Head length & 20.1 & $19.1-21.4$ & 19.9 \\
\hline 12 & Head width & 93.6 & $84.8-99.1$ & 92.7 \\
\hline 13 & Head depth & 60.9 & $48.6-66.3$ & 55.8 \\
\hline 14 & Mouth width & 35.9 & $32.6-41.2$ & 36.8 \\
\hline 15 & Eye diameter & 10.8 & $7.4-11.1$ & 9.8 \\
\hline 16 & Interorbital width & 31.6 & $26.6-36.6$ & 31.8 \\
\hline 17 & Nasal barbel length & 108.2 & $85.2-108.2$ & 95.2 \\
\hline 18 & Maxillary barbel length & 111.8 & $93.6-111.8$ & 100.5 \\
\hline 19 & Rictal barbel length & 65.9 & $55.1-70.2$ & 63.7 \\
\hline
\end{tabular}


connected with the El Misterio cave, no specimens of Trichomycterus have been found in the epigean streams from Mesa de los Santos plateau, near the cave El Misterio, and T. uisae has the classical troglomorphic character states (Trajano \& de Pinna, 1996; Romero \& Paulson, 2001; Bichuette \& Trajano, 2008).

Comparative material. Trichomycterus latistriatus: IAvH-P 4340, 1, 10.5 mm SL, Colombia: Santander: Río Negro, upper Lebrija River basin. Trichomycterus retropine: IAvH-P 99, 2, 8.38.7 mm SL, Colombia: Santander: Suarez River basin. Trichomycterus santanderensis: CAC-CDMB 35, holotype, $100.7 \mathrm{~mm}$ SL, Colombia: Cueva El Puente, upper Lebrija River basin. Trichomycterus straminius: IAvH-P 440, 2, 7.4-8.2 mm SL, Colombia: Santander: Suarez River basin. Trichomycterus striatus: IAvH-P 4348, 7.5 mm SL,Colombia: Santander: Río Frío, upper Lebrija River basin.

\section{Acknowledgments}

I would like to thank Carlos DoNascimiento for orientation, information about the new species and review of the text. Thanks are due to Juan D. Bogota (IAvH-P) and Javier Maldonado (IAvH-P) for the loan of specimens and for assistance during visits to their institution. Special thanks to Laura Lucia Marino-Zamudio and Mauricio Pardo-Peñaloza, who assisted to the speleological explorations resulting in the collection of the specimens here described. Jennifer Giron provided taxonomic identification of aquatic Hemiptera. Gail S. Ross, and José A. Mari Mutt kindly reviewed the text. This manuscript benefited from the suggestions of two anonymous reviewers. This project was supported in part by the Fish, Legumes and Wetland from the Santander Department project, funded by BIOMAS (Environmental Non-Government Organization) Santander - Colombia.

\section{Literature Cited}

Ardila-Rodríguez, C. A. 2006. Trichomycterus sandovali (Siluriformes, Trichomycteridae) una nueva especie de pez cavernícola para el departamento de Santander-Colombia. Peces del Departamento de Santander - Colombia, 2: 1-16.

Arratia, G. \& L. Huaquin. 1995. Morphology of the lateral line system and of the skin of diplomystid and certain primitive loricarioid catfishes and systematic and ecological considerations. Bommer Zoologische Monographien, 36:1-110.

Baskin, J. N. 1973. Structure and relationships of the Trichomycteridae. Unpublished Ph.D. Dissertation, City University of New York, New York. 389p.

Bichuette, M. E. \& E. Trajano. 2008. Ituglanis mambai, a new subterranean catfish from a karst area of Central Brazil, rio Tocantins basin (Siluriformes: Trichomycteridae) Neotropical Ichthyology, 6(1): 9-15.

Bichuette, M. E., M. C. C. de Pinna \& E. Trajano. 2008. A new species of Glaphyropoma: the first subterranean copionodontine catfish and the first occurrence of opercular odontodes in the subfamily (Siluriformes: Trichomycteridae). Neotropical Ichthyology, 6(3):301-306.
Castellanos-Morales, C. A. 2007. Trichomycterus santanderensis: A new species of troglomorphic catfish (Siluriformes, Trichomycteridae) from Colombia. Zootaxa, 1541: 49-55.

Costa, W J. E. M. \& F. A. Bockmann. 1993. Un nouveau genre néotropical de la famille des Trichomycteridae (Siluriformes: Loricarioidei). Revue Française de Aquariologie, 20: 43-46.

Dahl, G. 1971. Los Peces del Norte de Colombia. Ministerio de Agricultura, Instituto de Desarrollo de los Recursos Naturales Renovables INDERENA. Bogotá, Colombia, 391 p.

DoNascimiento, C. \& O. Villareal. 2005. Estatus taxonómico y sistemático de la población de bagres tricomictéridos de la cueva del Guácharo (Otophysi, Siluriformes). Pp. 44-50. In: Memorias del VIII Simposio Colombiano de Ictiología. Quibdó, Colombia.

DoNascimiento, C., O. Villarreal \& F. Provenzano. 2001. Descripción de una nueva especie de bagre anoftalmo del género Trichomycterus (Siluriformes, Trichomycteridae), de una cueva de la Sierra de Perijá, Venezuela. Boletín de la Sociedad Venezolana de Espeleología, 35: 20-26.

Eigenmann, C. H. 1918. The Pygidiidae, a family of South American catfishes. Memoirs of the Carnegie Museum, 7(5): 259-398.

Fernández, L. \& S. A. Schaefer. 2005. New Trichomycterus (Siluriformes: Trichomycteridae) from an offshore island of Colombia. Copeia, 2005(1): 68-76.

Ferraris Jr., C. J. 2007. Checklist of catfish recent and fossil (Osteichthyes: Siluriformes) and catalogue of siluriform primary types. Zootaxa, 1418: 1-628.

Maldonado-Ocampo, J. A., A. Ortega-Lara, J. S. Usma-Oviedo, G. Galvis-Vergara, F. A. Villa-Navarro, L. Vasquez-Gamboa, S. Prada-Pedreros \& C. A. Ardila-Rodriguez. 2005. Peces de los Andes de Colombia: Guía de Campo. Instituto de Investigación de Recursos Biológicos Alexander von Humboldt, Bogotá, D. C. Colombia, $346 \mathrm{p}$.

Munsell Soil Color Charts. 1994. Munsell Color Co. Baltimore, MD.

Nelson, J. S. 2006. Fishes of the World. 4th ed. John Wiley and Sons. Hoboken, NJ, USA, 601p.

de Pinna, M. C. C. 1989. A new Sarcoglanidinae catfish, phylogeny of its subfamily, and an appraisal of the phyletic status of the Trichomycterinae (Teleostei, Trichomycteridae). American Museum Novitates, 2950: 1-39.

de Pinna, M. C. C. 1992. Trichomycterus castroi, a new species of trichomycterid catfish from the Rio Iguaçu of Southeastern Brasil (Teleostei: Siluriformes). Ichthyological Exploration of Freshwaters, 3(1): 89-95.

de Pinna, M. C. C. \& W. B. Wosiacki. 2003. Family Trichomycteridae (Pencil or parasitic catfishes). Pp. 270-290. In: Reis, R. E., S. O. Kullander \& C. J. Ferraris, Jr. (Org.). Check List of the Freshwater Fishes of South and Central America. Edipucrs, Porto Alegre, Brazil. 729p.

Romero, A. \& K. M. Paulson. 2001. It's a wonderful hypogean life: a guide to the troglomorphic fishes of world. Environmental Biology of Fishes, 62: 86-112.

Sket, B. 1988. Speleobiological investigations in the Colombian Andes. Bioloski Vestnik, 36: 53-62.

Taylor, W. R. \& G. C. Van Dyke. 1985. Revised procedures for staining and clearing small fishes and other vertebrates for bone and cartilage study. Cybium, 9(2): 107-119.

Trajano, E. 2005. Evolution of lineages. Pp. 230-234. In: Culver, D. $\&$ W. White (Eds.). The Encyclopedia of Caves. Academic Press, San Diego, California, USA. 
Trajano, E. \& M. C. C. de Pinna. 1996. A new species of Trichomycterus from eastern Brazil (Siluriformes, Trichomycteridae). Revue Française d'Aquariologie, 23: 85-90.

Wheeler, Q. D. \& N. I. Platnick. 2000. The phylogenetic species concept (sensu Wheeler and Platnick). Pp. 55-69. In: Wheeler, Q. D. \& R. Meier. (Eds.). Species concepts and phylogenetic theory: a debate. Columbia University Press, New York, NY, USA.

Williams, J. 1990. Barrita y fluorita en la Mesa de Los Santos y Pescadero, Santander. Boletín Geológico, 31(2, 3): 1-17.

Wosiacki, W. 2002. Estudo das relações filogenéticas de Trichomycterinae (Teleostei, Siluriformes, Trichomycteridae) com uma proposta de classificação. Unpublished Ph. D. Dissertation, Instituto de Biociências, Universidade de São Paulo, São Paulo, Brazil. 324 p.

Accepted August, 2008

Published September 30, 2008 